\title{
SCHOOL LIBRARIANS DURING THE COVID-19
}

\author{
Touku Umar* \& Nasrullah*
}

*Library Science Department, Universitas Islam Negeri Alauddin Makassar

Email: oemartouk11@gmail.com, nasrullah.nasir@uin-alauddin.ac.id

(Submitted: 02-04-2021, Revised: 05-05-2021, Accepted: 03-06-2021)

DOI: $10.24252 / v 9 i 1 \mathrm{a} 8$

\begin{abstract}
ABSTRAK: Penelitian ini bertujuan untuk mengetahui peran dan kendala pustakawan sekolah dalam memberikan pelayanan di masa pandemi covid-19. Penelitian ini bersifat deskriptif dengan pendekatan kualitatif. Lokasi penelitian ini dilakukan di Kabupaten Gowa Provinsi Sulawesi Selatan dengan memilih 13 perwakilan sekolah Sekolah Menengah Atas (SMA), Sekolah Menengah Kejuruan (SMK) dan Madrasah Aliyah (MA) sederajat negeri maupun swasta. Teknik pengumpulan data dengan melakukan observasi, wawancara dan dokumentasi. Analisis data yang digunakan yakni reduksi data, penyajian data dan penarikan kesimpulan. Hasil penelitian menunjukkan bahwa peran pustakawan sekolah dalam memberikan pelayanan di masa pandemi covid-19 yakni memberikan pelayanan secara langsung dengan menerapkan protokol kesehatan, menyediakan sumber informasi digital atau e-book, menyebarkan informasi melalui aplikasi WhatsApp, meningkatkan dan membenahi sarana prasarana perpustakaan. Sedangkan kendala yang dihadapi yakni tidak siapnya pustakawan menghadapi kondisi, kurangnya fasilitas teknologi dan akses internet, kurangnya kompetensi pustakawan dan minimnya anggaran perpustakaan.
\end{abstract}

Kata kunci: Pustakawan sekolah; perpustakaan sekolah

ABSTRACT: This study aims to determine the roles and obstacles of school librarians in providing services during the Covid-19. This descriptive study used a qualitative approach. The researchers selected 13 representatives of high schools, vocational high schools, and madrasah aliyah at the same level as public and private. The data were obtained through observations, interviews, and documentation. The study found that school librarians have provided certain library services during the Covid-19 pandemic, namely providing direct services by implementing health protocols, providing digital information sources or e-books, disseminating information via WhatsApp, improving and fixing library infrastructures. Meanwhile, the obstacles faced by school librarians were unpreparedness to face the pandemic, lack of technology facilities and internet access, lack of competency, and minimum library budget.

Keywords: School librarian; school library

\section{INTRODUCTION}

Like other libraries in educational institutions, school libraries function, one of which is to support the teaching and learning process. Their important presence in schools is also mentioned in the Indonesian Government Regulation on National Education Standards Number 19 of 2005 which clearly stated that "the library is a mandatory prerequisite for a school". Another regulation, Law Number 43 of 2007 concerning Libraries, Article 23 paragraph 1 states that "every school/madrasah (boarding schools) organizes libraries that meet National Library Standards by 
following the National Education Standards", (Undang-Undang Republik Indonesia No. 43 Tahun 2007 Tentang Perpustakaan, 2007).

School libraries should be managed properly. For this reason, school librarians should also have good competence. Especially in the current era, where information seekers need faster and more accurate information. Without this competency improvement, librarians will be left behind and find it difficult to adapt. Sulistyo-Basuki, an expert in library science, explains that a librarian is "a person who provides and carries out library activities to provide services to the community by following the mission of the parent organization based on library science, documentation and information obtained through education", (Basuki, 2010).

Carrying out librarian duties is not an easy task, librarians face various obstacles to manage a library to be much better. A study conducted by (Fauruza, 2015) found that the problems of school librarians in managing libraries were human factors and the school environment. Human factors such as the ability of librarians themselves while for the school environmental factors such as lack of collaboration between the librarians and the schools, inadequate funds, and lack of facilities and infrastructure provided by the schools. Therefore, librarians' abilities are essential in optimizing services in libraries, not only in school libraries but also in other institutions expected to have competent librarians to get the best service for library patrons.

The current era of technology requires any profession to quickly make changes, including the librarian profession. Librarians are required to be more technologically in using advanced information technology. Librarians from various types of library institutions should improve their competence and transform their libraries to meet the era of information technology (Armen, 2019), especially now that it has been 2 years, Covid-19 has infected almost the whole world. All activities are mostly doing and done at home with the help of technology as seen today. At the end of December 2019, the World Health Organization (WHO) announced a new virus type Coronavirus Disease (COVID-19), which firstly appeared in Wuhan, China, and has also affected Indonesia in early 2020. The virus requires people to obey health protocols such as social distance to reduce the risks of Covid-19 virus infectious. Hence, the Indonesian Government announced to now make a crowded and work and learn at home. By studying from home, or online learning, of course, school libraries are not open or in other words no more receiving visits from its users. Therefore, school libraries as a support unit in education should provide electronic reading sources for the needs of online users who are active from home as accordingly stated by Suharti (2020), Adigun et al. (2020), and Owusu-Ansah et al (2019). This condition forces librarians to creative and innovative to fulfilling visitors' information needs and to support learning processes even in distance learning. Therefore, school librarians during this pandemic are required to act quickly and carefully to continue to provide services to their patrons. This study aims to determine the role of 13 selected school librarians and what are the obstacles they faced in providing services during the Covid-19 pandemic.

\section{PREVIOUS FINDINGS}

A study conducted by Jacqueline Solis and Robin L. Kear stated that librarian activities in Croatian Public Libraries during the Covid-19 outbreak include reading children's stories by recording and posting them on the library's Facebook page, online reading community meetings, online e-book recommendations, online quizzes, and online exhibitions (Solis \& Kear. L, 2020). Annaa Maria Tammaro (2020), in her study, explained that the existence of the Covid-19 emergency had encouraged library transformation by continuing to provide online services and providing access to digital libraries, renewed online communication from using the telephone to video conferences and social media. Muhammad Yousuf Ali dan Peter Gatiti (2020) in their paper, stated that the roles of librarians during this pandemic are to increase people's awareness through public health education, provide support to medical staff and researchers, and provide ongoing services to the community regarding the information needed. 
In school libraries, Nailah Hanum Hanany et al. (2020) studied the activity carried out by school librarians. In their paper, school librarians were doing online services by utilizing electronic library materials and information literacy services during the Covid-19 pandemic in this study. Another study by Putut Suharso et al. reveals that college libraries during the pandemic are required to provide digital services to communicate between library institutions and their users. During the Covid-19 pandemic, libraries can function as information services to support student and lecturer research by subscribing to several journal databases and e-books. In addition, the library provides information related to the Covid-19 cases, health literacy services, and research results regarding Covid-19 (Suharso et al., 2020). Librarians also provided information through social media such as WhatsApp in serving library users, Maisonah (2020). Besides, some also implemented library delivery services as explained by Erna Fitri Widayati (2020).

\section{RESEARCH METHODOLOGY}

This descriptive study used a qualitative approach which is to emphasizes the dynamics of the relationship between the observed phenomena and always uses scientific logic (Gunawan, 2013). The main purpose of qualitative research is to understand social phenomena or symptoms by explaining the form of a clear depiction of these social phenomena or symptoms in the form of a series of words (Sujarweni, 2014). The data were obtained from 13 selected school libraries located in Gowa Regency, South Sulawesi, Indonesia. These 13 library representatives are public and private at senior high schools. This research was conducted from January 2021 to March 2021. Besides, supporting documents related to the focus of the study were also collected. The data analysis used the data reduction method, where the researcher records everything that has been done during the research, then the researcher selects and summarizes the things that are considered important. After that, presenting the data in a brief description, making conclusions from the focused data, and systematically compiling it in a descriptive form.

Table 1. Schools' names and informants

\begin{tabular}{clc}
\hline No. & \multicolumn{1}{c}{ Schools } & Informants \\
\hline 1. & SMA Negeri 2 Gowa & Lib 1 \\
2. & SMA Negeri 8 Gowa & Lib 2, \\
3. & SMA Negeri 9 Gowa & Lib 3 \\
4. & SMA Negeri 11 Gowa & Lib 4 \\
5. & SMA Negeri 20 Gowa & Lib 5 \\
6. & SMA Muhammadiyah Gowa & Lib 6 \\
7. & SMA Swasta Guppi Samata Gowa & Lib 7 \\
8. & SMK Negeri 1 Gowa & Lib 8 \\
9. & SMK Negeri 3 Gowa & Lib 9 \\
10. & SMK Negeri 4 Gowa & Lib 10 \\
11. & SMK Negeri 5 Gowa & Lib 11 \\
12. & MA Madani Alauddin Gowa & Lib 12 \\
13. & MA Syekh Yusuf Gowa & Lib 13 \\
\hline
\end{tabular}




\section{RESULTS AND FINDINGS}

\section{School Librarians in Providing Services during the Covid-19}

\section{Providing services normally by adhering to health protocols}

A library is an organization engaged in the service sector, the quality of service is an essential thing because it is the spearhead of the library (Rodin, 2015). The better the service of a library, the better its image. Libraries that can provide excellent service have a good image, an image that gives added value to the library as an institution (Indahtianti \& Tjuparmah SK, 2013). School libraries are expected to continue providing services during this pandemic so that the information needs of students and teachers can be fulfilled even in unusual situations. The pandemic does not completely paralyze services in libraries, of course, there are roles and ways for librarians to continue to meet their visitors. As interviewed that, "we continue to provide services in the library by following health protocols for students visiting the library and providing convenience in borrowing books with a one-semester return period" (Lib 10). It is said that "the library continues to provide services... but there is a limitation the number of students who visit the library with the rule that only three classes per day can use the service and keep following the health protocols because the library room and reading chairs are limited" (Informant: Lib 2). So did Lib 9 who stated, "library services are still open but operating hours of service are reduced from 8 to 11 o'clock and reduced working days from Monday to Thursday". Even in a pandemic situation, librarians still carry out their roles. The school library must be able to play a role, especially in helping students to achieve educational goals in schools (Mangnga, 2015).

\section{Providing digital information sources or e-book}

A School library is a unit in school that functions as an information center and provides all references or learning resources needed by teachers and students (Bala \& Nasir, 2020). School librarians play important role in organizing the library, such as providing books. Libraries need books as assets and their librarians can empower them (Suwarno, 2016). Advanced technology has now penetrated libraries. Printed books are also provided in digital form or are commonly referred to as e-books. E-books are digital books that can be accessed using sophisticated technological tools such as handphones and laptops. The e-book collection is a library collection that has changed form from a printed collection to an electronic form (Prabowo \& Heriyanto, 2013).

This pandemic has required people to obey health protocols such as social distance, but technology tools still allow people to communicate. Activities such as teaching, meetings, and so on can be done through video calls or other technologies. E-books are also very important during this pandemic so that school libraries continue to serve. For example in what Lib 5 says, "to provide the information needs of students and teachers, we provide e-books that can be downloaded from bse.belajar.kemendikbud.go.id". So did Lib 6 who said, "we provide a source of information to students and teachers by digitizing books using the Adobe Scan application, the books that we choose are according to the needs of students and teachers". Providing e-books is also mentioned by Lib 11. Libraries as a support unit in education must provide a source of electronic reading materials to the patrons who are now studying from home (Suharti, 2020).

\section{Disseminating information through WhatsApp}

Technology has now developed very rapidly. Because of the advanced technology, now everyone is very easy to access information. Information is considered very important in today's information society because the information has become a necessary, commodity, and strength. (Rumani, 2017). Besides, the technology also has made an easy to disseminate and share information, one media is the presence of social media as an online-based communication tool that can be used to communicate, share information and socialize. Social media is one of the most widely used or as communication media to socialize with other people in cyberspace as noted by Prihandoyo \& R Sudarwo (2020). One of the most used social media is WhatsApp application 
(Prajana, 2017). This application is an application that is used to have text conversations, share information, and send pictures or videos.

During the pandemic, the WhatsApp application is very much needed to support communication between individuals. Health protocols like keep social distancing make everyone unable to convey information directly. Libraries as information organizations are expected to be more creative in disseminating information even during the pandemic. School librarians have used such social media to interact with their patrons as said by Lib 13, "we collaborated with teachers by creating a Whatsapp group as a medium for disseminating information to students". Similarly, Lib 8 said, "we use WhatsApp to inform the schedule for returning and borrowing books in class groups that have been created". So did Lib 2, "we use WhatsApp if students need a source of information by sharing a link or website related to the information needed".

Therefore, the librarian's role in disseminating information on the WhatsApp application is one way of supporting distance learning or online learning, and this role also does not diminish the function of the library as an information center. Libraries as a source of information must be able to transform into an ideal library in supporting the learning process (Ramadhanti et al., 2020).

\section{Improving and repairing library facilities}

Library management must be supported by good facilities and infrastructure. The rapid development of libraries must be supported by providing optimal room facilities and infrastructure (Mutia, 2011). Library facilities and infrastructure are one of the basic needs in supporting the activities in it (Mustika \& Rahmah, 2015). During this pandemic, student activity in schools is undoubtedly reduced and even non-existent. This is certainly an opportunity for librarians to fix all library infrastructure so that later they can provide better changes in managing the library as said by Lib 7, "we fix the library room, cleaning the room, clearing dust from books, and changing chairs or tables that are no longer suitable for use". As well Lib 12 and Lib 1, who said, "we make improvements in the library, such as renovating bookshelves, selecting and sorting books that are still feasible or unfit for display, and decorating the library to make it look attractive".

Improvement of facilities and infrastructure needs to be done in the library to support the learning process of students and teachers. The learning process that is carried out well may not necessarily provide maximum results without being supported by adequate library facilities and infrastructure (Bramasta \& Irawan, 2017).

\section{Obstacles of School Librarians in Providing Services during the Covid-19}

\section{Librarians not ready to face the pandemic}

The Covid-19 has almost destroyed all aspects of life, including in education manners, which requires changing learning methods from face-to-face to distance learning. Such condition impacts libraries as a means of supporting learning in schools. School librarians must quickly adapt to this condition so that the school library continues to function. Librarians must always prepare themselves for the changes that occur and must be able to react and act appropriately so that the librarian's duties can continue under any circumstances (Arlan, 2020). School librarians are required to think and act harder in responding to the changes especially in libraries that still provide services traditionally. With the current pandemic condition, all services in the library must switch to prioritizing the maximum use of technology (Riani \& Handayani, 2020).

Several school librarians commented on this, for example, Lib 3 said "this pandemic condition made us think hard to keep library services running. Moreover, our library is not ready to provide online services". Similarly, Lib 13 and Lib 4 stated that the Covid-19 makes us confused and do not know what activities to do in the library, especially since the library is still using the manual system or with inadequate facilities. 


\section{Inadequate technology facilities and internet access}

The existence of technology in the library at this time is of course very much needed to facilitate access to information in the library. The use of technology in the library certainly also makes librarian's work easier, switching from traditional to automated. Information technology devices have changed work patterns, including in libraries, which were originally conventional and simple work patterns demanding automation-based and more up to date (Fahrizandi, 2020). The internet in the library is also a necessity and allowing access to a wide range of information sources, both free and at a certain cost. The internet is used in the library as a means of searching for information and means of communication in services (Wibawanto, 2018). During this pandemic, technology and internet facilities are needed to provide digital or online-based services so that libraries continue to function as sources of information in schools. Libraries are expected to be able to provide and utilize online services to reach users by providing information services through their laptops and handphones (Anyanwu et al., 2020). However, from the interviews, it is said that technological facilities in the school libraries are still inadequate so it causes librarians to be difficult and cannot provide digital-based services to teachers and students to meet their information needs.

\section{Poor competency}

In the work environment, competence is a benchmark in setting a person's professional standards, especially since we have entered the era of the 4.0 industrial revolution where people who have competencies have the opportunity to compete in the world of work competition. The industrial era requires a competent workforce that can adapt to technology (Asriandi \& Putri, 2020). Librarians must also have good competence to provide maximum service to the patrons. As a librarian, he/she must have competencies that make the library services develop and have quality (Azmar, 2015). One of the competencies that librarians must have in this era is the ability to adapt to technology and this is an obligation. Librarians are required to continue to improve their competence by increasing their abilities, skills, and knowledge in technology (Aini \& Istiana, 2018). In addition, competence in the field of libraries is also the main thing, such as having taken education in library science background as evidenced by a diploma or having carried out training proven by a certificate. The competence of librarians during this pandemic is very much needed because of the demands of the current conditions, making librarians more adaptable and work more professional. However, related to the competencies, school libraries still admit their lack of competence. Thus, it will be more difficult to be able to provide a more excellent service

\section{Inadequate Library Budget}

Good library management always concerns budget planning. The budget is designed to determine what will be needed in carrying out library programs, both short-term and long-term programs. The library budget is essential because it is related to the development of libraries, good facilities and infrastructure, and the collections in libraries. So planning a library budget is very important to obtain complete library facilities and infrastructure to support library development. According to the Law, the schools must allocate as much as $5 \%$ from the School Operational Assistance (BOS), it is not including personnel salary expenditures. Not many schools have or can do that. Moreover, if the library wants to switch to digital services, it must have adequate money to buy hardware and other necessities. Based on the interviews that the school libraries do not provide sufficient allocation for technology equipment and other necessary things to support learning processes during the pandemic.

\section{CONCLUSION}

The pandemic has made school libraries think hard to be able to continue to provide services to their users, especially for libraries whose facilities and infrastructure are still very lacking. Nevertheless, the libraries in question are still trying to provide the services they can provide, for example by using the WhatsApp application to deliver the information needed. The results of this 
study are expected to be a reference material and encouragement for school librarians who have not done any activities in their libraries during this pandemic to get up and try to do something to provide services in the library. School librarians are also required to develop their competence, especially in the field of technology so that they can build digital or online-based services. Librarians are expected to change their minds and paradigm, which previously served traditionally to become information and digital literacy creators (Bakti et al., 2020).

The Covid-19 has made library service run in unusual. Therefore, the role of the school library is highly expected. Based on the results, the school librarians have been still trying to serve directly by implementing health protocols, providing digital information sources or e-books, disseminating information through the WhatsApp application, improving and fixing the library infrastructure. Meanwhile, the obstacles faced are the librarian's unpreparedness to face the conditions, the lack of technical facilities and internet access, the librarian's lack of competence, and the minimum library budget.

\section{REFERENCES}

Adigun, G. O., Okuonghae, O., \& Mamudu, P. A. (2020). Interrogating the Role of Libraries in the Fight against COVID-19 Pandemic: The Nigerian Perspective. International Journal of Knowledge Content Development \& Technology, 10(4), 47-64.

Aini, R. N., \& Istiana, P. (2018). Kompetensi Pustakawan Perguruan Tinggi dalam Era Revolusi Industri 4.0. Jurnal Pustakawan Indonesia, 17(2), 71-78.

Ali, M. Y., \& Gatiti, P. (2020). The COVID-19 (Coronavirus) pandemic: reflections on the roles of librarians and information professionals. Health Information and Libraries Journal, 37(2), 158-162.

Anyanwu, E., Ogbonna, J., \& Nwaigwe, U. (2020). Repositioning Academic Libraries for Provision of Effective Services in time of Corona Virus Pandemic. Journal of Library and Information Sciences, 8(2), 8-10.

Arlan. (2020). Inovasi Pustakawan Menghadapi Perubahan di Masa Pandemi Covid-19. Jurnal Almaktabah, V(2), 149-165.

Armen, A. (2019). Kesiapan pustakawan di era teknologi informasi. Maktabuna: Jurnal Kajian Kepustakawanan, 1(2), 161-170.

Asriandi, \& Putri, K. N. (2020). Kompetensi Generasi Z dalam Menghadapi Era Revolusi Industri 4.0 (Studi Kasus Perguruan Tinggi di Makassar). Seiko: Journal of Management \& Business, 3(3), 184-200.

Azmar, N. J. (2015). Peran Pustakawan dalam Meningkatkan Kualitas Layanan di Perpustakaan. Iqra: Jurnal Perpustakaan Dan Informasi, 9(2), 223-234.

Bakti, L. A., Prasetyadi, A., Nugroho, D. W. A., Trianggoro, C., Rosiyan, N. R., \& Subagyo, H. (2020). Innovation in Library Services Post COVID-19 Pandemic. International Conference on Documentation and Information, 3, 25-33.

Bala, R., \& Nasir, R. (2020). Mengelola Perpustakaan Sekolah. Lakeisha.

Basuki, S. (2010). Pengantar Ilmu Perpustakaan. Universitas Terbuka.

Bramasta, D., \& Irawan, D. (2017). Persebaran Sarana dan Prasarana Perpustakaan Sekolah Dasar Berbasis Sistem Informasi Grafis. Jurnal Khazanah Pendidikan, 11(1), 39-67.

Fahrizandi. (2020). Pemanfaatan Teknologi Informasi di Perpustakaan. Tik Ilmeu : Jurnal Ilmu Perpustakaan Dan Informasi, 4(1).

Fauruza, A. (2015). Problematika Tenaga Perpustakaan Sekolah di SMPN 3 Padang Panjang. Jurnal Ilmu Informasi Perpustakaan Dan Kearsipan, 4(1), 90-94.

Gunawan, I. (2013). Metode Penelitian Kualitatif. Bumi Aksara.

Hanany, L. N. H., Robi'in, Sudirman, E., \& Wardianah, Y. (2020). Pelayanan Perpustakaan di Masa Pandemi Covid-19. Jurnal Pusat Perpustakaan UIN Sunan Gunung Djati Bandung, 1.

Indahtianti, V., \& Tjuparmah SK, Y. (2013). Hubungan Pelayanan Sirkulasi dengan Pembentukan Citra Perpustakaan (Studi Deskripsi di Perpustakaan Universitas Pendidikan Indonesia). 
Edulib: Journal of Libarary and Information Science, 3(1), 59-68.

Maisonah, M. (2020). Auto Whatsapp Sebagai Alternatif Layanan Perpustakaan pada Masa Pandemi Covid-19 di IAIN Curup. Tik Ilmeu : Jurnal Ilmu Perpustakaan Dan Informasi, 4(2), 195.

Mangnga, A. (2015). Peran perpustakaan sekolah terhadap proses belajar mengajar di sekolah. Jupiter: Jurnal Bidang Ilmu Perpustakaan, Informasi dan Komputer, XIV(1), 38-42.

Mustika, P., \& Rahmah, E. (2015). Pengaruh Sarana dan Prasarana Perpustakaan Terhadap Minat Kunjungan Siswa SMPN 1 Batang ANAI. Jurnal Ilmu Informasi Perpustakaan dan Kearsipan, 4(1), 305-314.

Mutia, F. (2011). Sarana dan Prasarana Ruang Perpustakaan sebagai Aspek Kekuatan dalam Mengembangkan Perpustakaan. Jurnal Palimpsest, 3(1), 1-8.

Owusu-Ansah, C. M., Rodrigues, A. da S., \& van der Walt, T. B. (2019). Integrating digital libraries into distance education: A review of models, roles, and strategies. Turkish Online Journal of Distance Education, 20(2), 89-104.

Prabowo, A., \& Heriyanto. (2013). Analisis Pemanfaatan Buku Elektronik ( E-Book ) oleh Pemustaka di Perpustakaan SMA Negeri 1 Semarang. Jurnal Ilmu Perpustakaan, 2(2).

Prajana, A. (2017). Pemanfaatan Aplikasi Whatsapp dalam Media Pembelajaran Di UIN Ar-Raniry Banda Aceh. Jurnal Pendidikan Teknologi Informasi, 1(2), 122-133.

Prihandoyo, W. B., \& R sudarwo. (2020). Pola Penggunaan Media Sosial Whatsapp dalam Pemenuhan Informasi Mahasiswa Universitas Terbuka Mataram. Jurnal Riset Akuntasi Terpadu, 13(2), 208-216.

Ramadhanti, D., Yanda, P. D., \& Yenti, E. (2020). Peran Perpustakaan sebagai Pendukung Pembelajaran Jarak Jauh di Masa Pandemi Covid-19. Libraria: Jurnal Perpustakaan, 8(1), $1-30$.

Undang-Undang Republik Indonesia No. 43 Tahun 2007 Tentang Perpustakaan, (2007).

Riani, N., \& Handayani, S. N. (2020). Dampak Stres Kerja Pustakawan pada Masa Pandemi Covid19 Terhadap Layanan Perpustakaan Perguruan. Fihris: Jurnal Ilmu Perpustakaan Dan Informasi, 15(1), 97-114.

Rodin, R. (2015). Urgensi Kualitas Pelayanan Perpustakaan Perguruan Tinggi. Al-Kuttab Jurnal Perpustakaan Dan Informasi, 2(1), 1-20.

Rumani, S. (2017). Aspek Hukum dan Bisnis Informasi. Universitas Terbuka.

Solis, J., \& Kear.L, R. (2020). Online Activities of Croatian Public Libraries During COVID-19 Spring Lockdown. International Information and Library Review, 52(4), 318-319.

Suharso, P., Arifiyana, I. P., \& Wasdiana, M. D. (2020). Layanan perpustakaan perguruan tinggi dalam menghadapi pandemi Covid-19. Anuva, 4(2), 271-286.

Suharti, A. (2020). Layanan Perpustakaan Di Masa Pandemi. Buletin Perpustakaan Universitas Islam Indonesia, 3(2), 53-63.

Sujarweni, V. W. (2014). Metodologi Penelitian. Pustaka Baru Press.

Suwarno, W. (2016). Perpustakaan \& Buku : Wacana Penulisan \& Penerbitan. Ar-ruzz Media.

Tammaro, A. M. (2020). COVID 19 and Libraries in Italy. International Information and Library Review, 52(3), 216-220.

Wibawanto, A. (2018). Penggunaan Internet dalam Perpustakaan. Pustakaloka: Jurnal Kajian Informasi Dan Perpustakaan, 10(2).

Widayati, E. F. (2020). Delivery Service Pustakawan di Era New Normal. Pustakaloka: Jurnal Kajian Informasi Dan Perpustakaan, 12(2), 152-170. 